\title{
Rock magnetism of sediments in the Angola-Namibia upwelling system with special reference to loss of magnetization after core recovery
}

\author{
Toshitsugu Yamazaki ${ }^{1}$, Peter A. Solheid ${ }^{2}$, and Gina M. Frost ${ }^{3}$ \\ ${ }^{1}$ Geological Survey of Japan, Tsukuba 305-8567, Japan \\ ${ }^{2}$ Institute for Rock Magnetism, University of Minnesota, Minneapolis, MN 55455-0128, U.S.A. \\ ${ }^{3}$ Hawaii Institute of Geophysics and Planetology, University of Hawaii, Honolulu, HI 96822, U.S.A.
}

(Received December 9, 1999; Revised March 13, 2000; Accepted March 15, 2000)

\begin{abstract}
A rock magnetic study was performed on sediment cores from four sites in the South Atlantic off the western coast of Africa, which were taken during the Ocean Drilling Program Leg 175 (Sites 1078, 1082, 1084, and 1085). The sites are within the Angola-Namibia upwelling system, and the sediments have a high total-organic-carbon content. Concentration of ferrimagnetic minerals at these sites is very low, and the magnetic susceptibility is dominated by paramagnetic and diamagnetic minerals. Severe and rapid loss of remanent magnetization occurred during storage of the cores, with less than $10 \%$ of the initial intensity remaining a few months after core recovery. The loss of magnetization may prevail in organic-rich sediments. Changes of magnetic properties with time were examined using samples that were kept frozen before the experiment. Hysteresis parameters and the ratio of ARM (anhysteretic remanent magnetization) to SIRM (saturation isothermal remanent magnetization) indicate increases in the average magnetic grain size with the decay of magnetization, which suggests preferential dissolution of finer magnetic minerals. Loss of low-coercivity magnetic minerals with time was estimated from the decrease of $\mathrm{S}$ ratios. Low-temperature magnetometry revealed the presence of magnetite in the sediments even after the completion of sulfate reduction. Magnetization attributable to magnetite decreased with the loss of magnetization. This suggests the transformation of magnetite into non-magnetic phases, which is consistent with the decrease of $S$ ratios.
\end{abstract}

\section{Introduction}

Sediments are the only material which may have continuously recorded the variations of the past geomagnetic field. Paleomagnetists have been making efforts to deduce relative paleointensity variations and details of geomagnetic field behavior during polarity transitions utilizing marine and lacustrine sediment cores (e.g. Hartl and Tauxe, 1996; Channell and Lehman, 1997; Guyodo and Valet, 1999; Yamazaki, 1999). Sediments have also been used for studies on environmental rock magnetism, which aims to recover paleoenvironments and paleoclimates utilizing rock-magnetic characteristics of the sediments such as concentration, mineralogy, and grain size of magnetic minerals (e.g. Verosub and Roberts, 1995; Colin et al., 1998; Hounslow and Maher, 1999). To enhance the resolution of paleo- and rock-magnetic records, it is necessary to use rapidly accumulated sediments. Such sediments are usually within high productivity provinces with a high supply of organic matter, which results in intensive chemical reactions involving dissolution and precipitation of minerals. To enhance the reliability of paleomagnetic and paleoenvironmental records, it is thus vital to understand the diagenetic activities, in particular those of iron-bearing minerals. A number of rock-magnetic and geochemical investigations on marine surface sediments were performed so far, especially on the dissolution and precipitation of iron-bearing

Copy right (C) The Society of Geomagnetism and Earth, Planetary and Space Sciences (SGEPSS); The Seismological Society of Japan; The Volcanological Society of Japan; The Geodetic Society of Japan; The Japanese Society for Planetary Sciences. minerals at the oxic-redox boundary (e.g. Karlin and Levi, 1983; Karlin et al., 1987; Torii, 1997; Haese et al., 1998).

Recently, rapid and severe loss of remanent magnetization during storage after core recovery has been reported on anoxic marine sediments taken by the Ocean Drilling Program (ODP), sapropels from the eastern Mediterranean Sea recovered during Leg 160 (Roberts et al., 1999), and organicrich hemipelagic sediments of Leg 167 from the California margin (Richter et al., 1999). In the latter case, it was found that magnetization of only about $10 \%$ or less remained several months after core recovery. Oldfield et al. (1992) also reported loss of magnetization during storage of lake sediments. Fidelity of paleo- and rock-magnetic records on marine sediments could seriously be impaired if this phenomenon prevails and has been overlooked.

In this paper, we document in detail the decay of remanent magnetization intensity after coring which occurred widely in sediments of ODP Leg 175 off the western coast of Africa in the South Atlantic. We investigate changes in magnetic properties associated with the intensity decrease, which was not reported previously. Then we discuss possible processes of the magnetic alteration.

\section{Geological Background}

During ODP Leg 175, sediment cores were taken at thirteen sites off the western coast of Africa between $5^{\circ}$ and $32^{\circ} \mathrm{S}$ (Wefer et al., 1998). The main purpose of the leg was to investigate the paleoceanography of the Angola-Benguela 


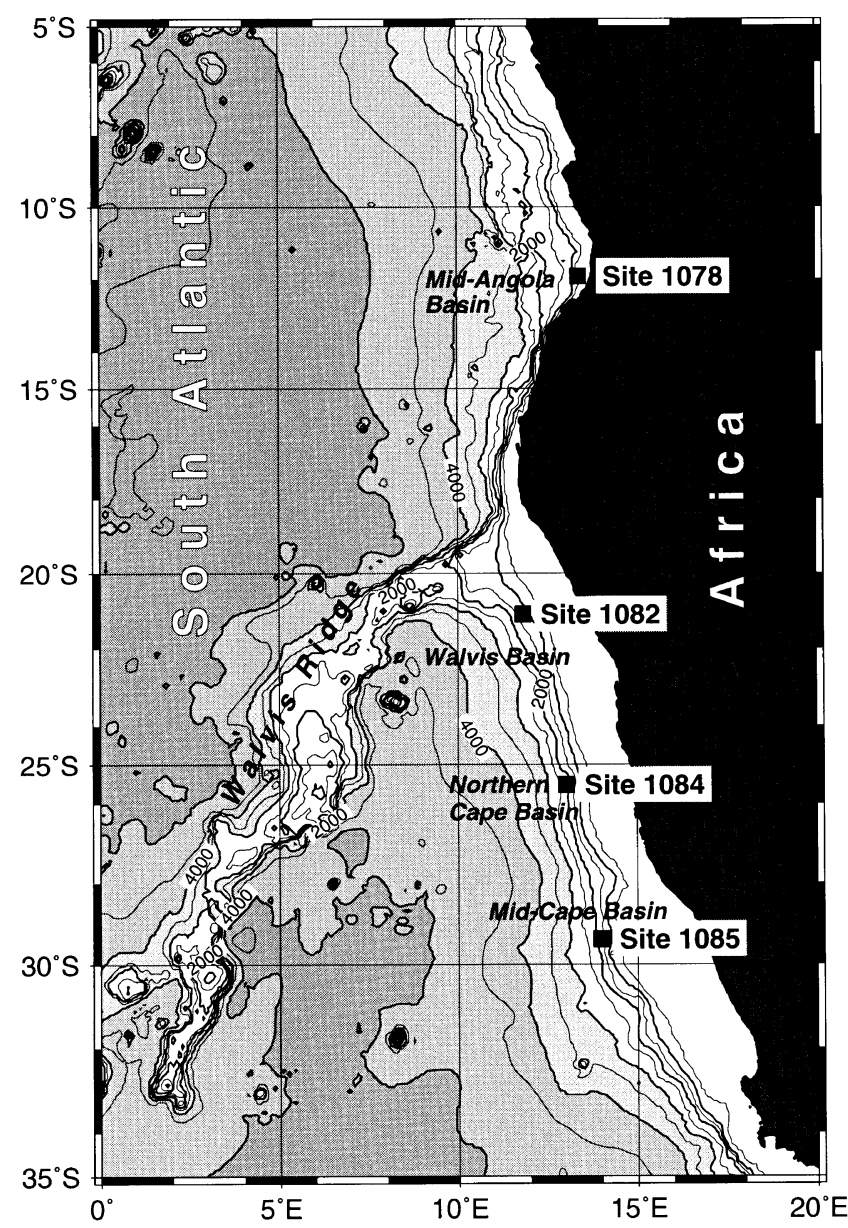

Fig. 1. Locality map of coring sites. Bathymetric contours are at $500 \mathrm{~m}$ intervals.

currents. Sediments from four sites out of thirteen, Sites 1078, 1082, 1084, and 1085 (Fig. 1), were used in this study. This area contains one of the major upwelling regions in the world, and is characterized by organic-rich greenish sediments with intense diagenetic activity.

Site 1078 is in the Mid-Angola Basin off Lobito, and its water depth is $427 \mathrm{~m}$. The site is between the highproductivity regions to both the north and south, and thus less affected by coastal upwelling. The sediments are composed predominantly of olive-gray silty clay with nannofossils and foraminifers (Pufahl et al., 1998). The age of the bottom of the hole at $160 \mathrm{~m}$ is estimated to be younger than 0.46 m.y. based on biostratigraphy (Giraudeau et al., 1998). The extremely high sedimentation rate, up to $600 \mathrm{~m} / \mathrm{m}$.y., is probably caused by the supply of silt from vigorous coastal erosion. Total organic carbon (TOC) content is high, about $3 \mathrm{wt} \%$ on average, which indicates high primary productivity (Murray et al., 1998). Sulfate reduction was completed within the top $15 \mathrm{~m}$ of the sediments.

Site 1082 in the Walvis Basin and in particular Site 1084 in the Northern Cape Basin lie close to the major upwelling center along the coast of southwest Africa. The water depths are $1280 \mathrm{~m}$ at Site 1082 and $1992 \mathrm{~m}$ at Site 1084. At Site 1082, nannofossil- and foraminifer-rich greenish clay was deposited during the upper Pleistocene with an average sedi- mentation rate of about $100 \mathrm{~m} / \mathrm{m} . \mathrm{y}$. The Brunhes-Matuyama polarity boundary $(0.78 \mathrm{Ma})$ occurs at about 80 meters composite depth (mcd). Average TOC content at Site 1082 is about $5 \mathrm{wt} \%$, and sulfate reduction was completed within the top $20 \mathrm{~m}$ (Murray et al., 1998). The sedimentation rate at Site 1084 was higher, about $200 \mathrm{~m} / \mathrm{m}$.y. on average during the Brunhes Chron, which reflects a greater proximity of this site to the area of highest productivity. The upper Pleistocene sediments are composed of olive-gray nannofossil clay and nannofossil ooze with intercalated organic-rich black layers. Concentration of TOC was extremely high at Site 1084: an average of $8 \mathrm{wt} \%$ with a maximum approaching $20 \mathrm{wt} \%$. Sulfate reduction was completed within several meters.

Site 1085 is located in the southern part of the Cape Basin with water depth of $1713 \mathrm{~m}$. The sediments consist of greenish nannofossil-foraminifer ooze and nannofossil ooze, and the sedimentation rate during the Pleistocene is about 50 $\mathrm{m} / \mathrm{m}$.y. The sediments of this site have lower TOC content than the other three sites, about $1 \mathrm{wt} \%$ on average, and sulfate reduction continues down to about 40 meters below seafloor (mbsf).

\section{Method}

Remanent magnetization of all archive half sections of the cores was measured onboard the JOIDES Resolution using a 2G Enterprises pass-through cryogenic magnetometer at 5 $\mathrm{cm}$ intervals. Discrete samples were taken onboard from the working half of the cores (one per each $1.5 \mathrm{~m}$ section). Remanent magnetization of discrete samples of Holes 1084A and $1085 \mathrm{~A}$ were measured onboard within a few days after the core recovery, and those of Holes 1078A, 1078B, and $1082 \mathrm{~A}$ were measured after the cruise (about 45 days after core-recovery of Hole 1082A) at the Geological Survey of Japan (GSJ) using a $2 \mathrm{G}$ cryogenic pass-through magnetometer. The GSJ magnetometer has an in-house designed sample-tray system with a magnetic moment in the order of $10^{-11} \mathrm{Am}^{2}$, which is significantly less magnetic than the one provided by the manufacturer of the magnetometer and the system onboard the JOIDES Resolution. For Hole 1082C cores, u-channel samples were taken from working halves and discrete samples from temporary-archive halves at the Bremen Core Repository about three months after the cruise for onshore paleomagnetic studies. The discrete samples of Hole $1082 \mathrm{C}$ were measured about six months after the corerecovery, and u-channels about one year.

Low-field magnetic susceptibility of whole core sections was measured onboard the JOIDES Resolution at 2 to $4 \mathrm{~cm}$ intervals using a Bartington MS-2 susceptometer with a sensing loop of $8 \mathrm{~cm}$ diameter. The data were converted to volumetric SI values. Magnetic susceptibility of discrete samples was measured at GSJ after the cruise using a KappaBridge KLY-3S susceptometer.

In order to study magnetic alteration after core recovery, changes of magnetic properties with time were examined on samples from Sites 1078, 1082, and 1084; one per each $9.5 \mathrm{~m}$ core for Core $1078 \mathrm{~A}-1 \mathrm{H}$ through $7 \mathrm{H}$ and $1082 \mathrm{~A}-1 \mathrm{H}$ through $9 \mathrm{H}$, and one per each three cores for Core 1084A$1 \mathrm{H}$ through $14 \mathrm{H}$. The samples were purged in nitrogen and frozen immediately after core recovery. Changes with time in the acquisition of anhysteretic remanent magnetization 


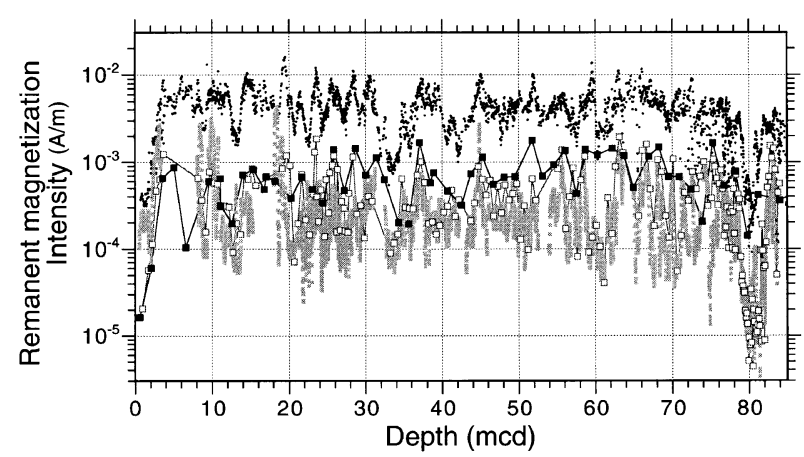

Fig. 2. Intensity of remanent magnetization of Site 1082 samples above 85 meter composite depth (mcd) measured four different times after core recovery. Half-core sections of Holes $1082 \mathrm{~A}$ and 1082C were measured onboard JOIDES Resolution after about one day (black dots), discrete samples of Hole 1082A were measured onshore after 45 days (solid squares), discrete samples of Hole $1082 \mathrm{C}$ after six months (open squares), and u-channel samples of Hole $1082 \mathrm{C}$ after 12 months (gray squares without connecting lines). All data are after AF demagnetization at $20 \mathrm{mT}$. The Brunhes-Matuyama polarity transition occurs at about $80 \mathrm{mcd}$.

(ARM) and isothermal remanent magnetization (IRM), and low-field magnetic susceptibility $(\chi)$ were monitored after thawing at room temperature (but not dried). The samples were stored in an ambient magnetic field before, during, and after thawing. The ARM and IRM were freshly imparted prior to each measurement, and in the same orientation each time. The ARM was given by superposing a DC biasing field of $0.1 \mathrm{mT}$ on a smoothly decreasing alternating field (AF) with a peak of $80 \mathrm{mT}$. With a pulse magnetizer, IRM of $0.3 \mathrm{~T}$ were imparted on a sample in the opposite direction after an IRM of $2.5 \mathrm{~T}$ was given, and $\mathrm{S}$ ratio $\left(\mathrm{S}_{-0.3 \mathrm{~T}}\right)$ were calculated according to the definition of Bloemendal et al. (1992):

$$
S_{-0.3 \mathrm{~T}}=\left(1-\mathrm{IRM}_{-0.3 \mathrm{~T}} / \mathrm{IRM}_{2.5 \mathrm{~T}}\right) / 2
$$

Low-temperature magnetometry was performed with a low-temperature SQUID susceptometer (Quantum Design MPMS-XL5) for investigating the magnetic mineralogy and magnetic grain size of frozen and unfrozen samples. First, an IRM of $2.5 \mathrm{~T}$ was imparted to a sample at 250 or $300 \mathrm{~K}$, and magnetization changes with temperature were measured by cycling the temperature between 250 (or 300) and $6 \mathrm{~K}$ in a nearly zero field. Next, an IRM of $2.5 \mathrm{~T}$ was given to the sample after having been cooled down to $6 \mathrm{~K}$ in a zero field, and thermal demagnetization of the IRM up to 250 or $300 \mathrm{~K}$ was measured. Magnetic hysteresis curves at $250 \mathrm{~K}$ were also measured using the SQUID susceptometer. The maximum applied field was $2.5 \mathrm{~T}$.

\section{Results}

Remanent magnetization of Site 1082 samples were measured at four different times after core recovery; about one day for half-core sections of Holes 1082A and 1082C, 45 days for discrete samples of Hole 1082A, six months for discrete samples and 12 months for u-channel samples of Hole 1082 C. Significant and rapid loss of remanent intensity occurred, and only about $5 \%$ of the original intensity remained after one year (Figs. 2 and 3). Variations in remanent intensity after the loss of magnetization is almost

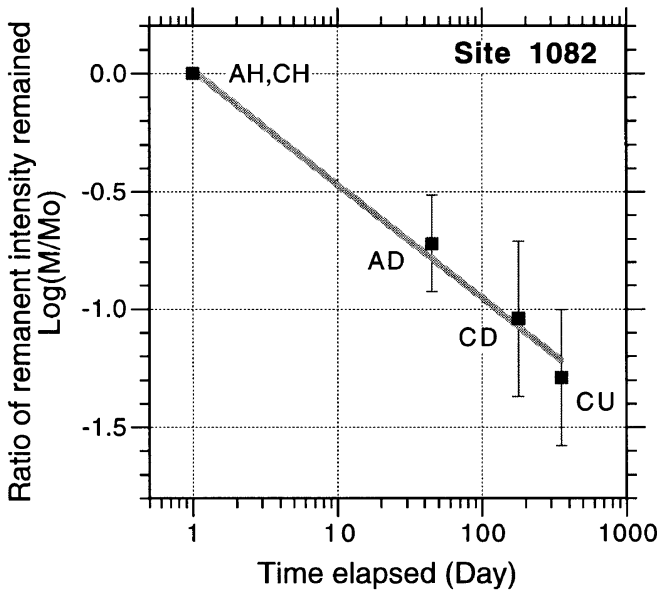

Fig. 3. Decay of remanent intensity of Site 1082 samples with time since core recovery: ratio of remanent intensities at on-shore measurements to those at on-board half-core measurements. The mean and standard deviation $(\sigma)$ of samples from 20 to $70 \mathrm{mcd}$ in Fig. 2 are presented. AH: half-core sections of Hole 1082A, $\mathrm{CH}$ : half-core sections of Hole 1082C, AD: discrete samples of Hole 1082A, CD: discrete samples of Hole 1082C, and CU: u-channel samples of Hole 1082C.
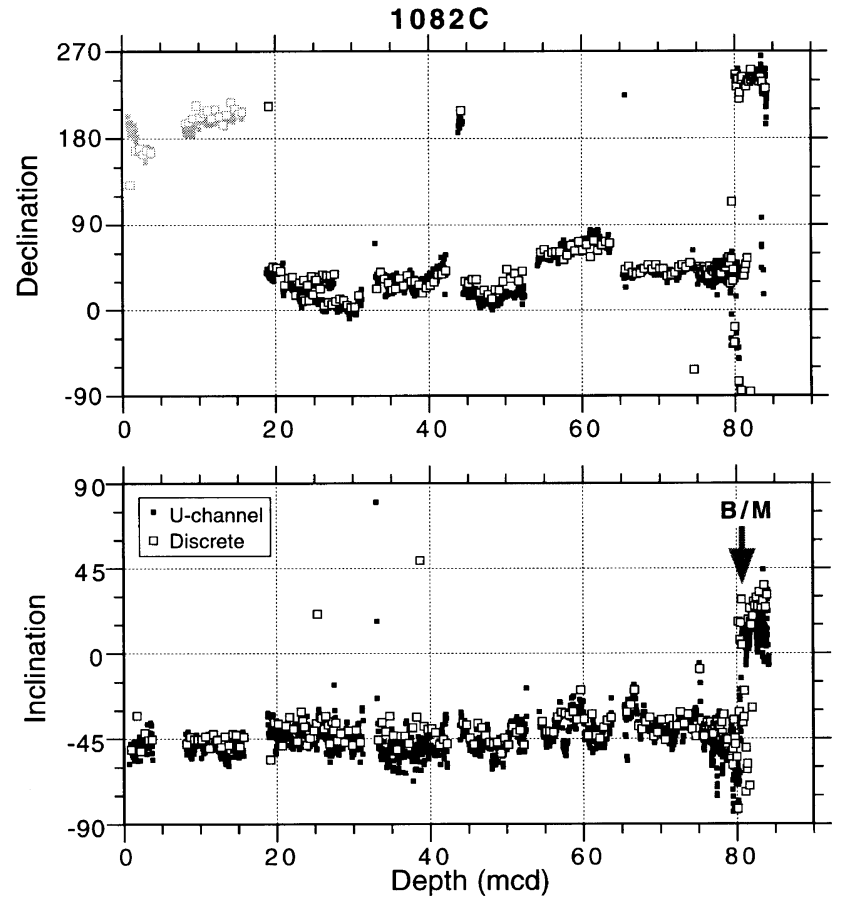

Fig. 4. Declination and inclination of remanent magnetization of Hole 1082C cores before and after intensity loss. Solid symbols indicate half-core sections measured onboard the JOIDES Resolution, and open squares indicate discrete samples measured onshore six months later. Cores below 18 mcd were azimuthally oriented using the Tensor tool, whereas cores above this depth were not oriented. The Brunhes-Matuyama polarity boundary occurs at about $80 \mathrm{mcd}$. All data are after AF demagnetization at $20 \mathrm{mT}$.

parallel to the original variations. A sharp drop in intensity at the Brunhes-Matuyama polarity boundary at about 80 mcd was observed commonly in all four records. Directions of remanent magnetization, on the other hand, showed no change (Fig. 4), which implies that no growth of new 
(a) Hole 1078A\&B

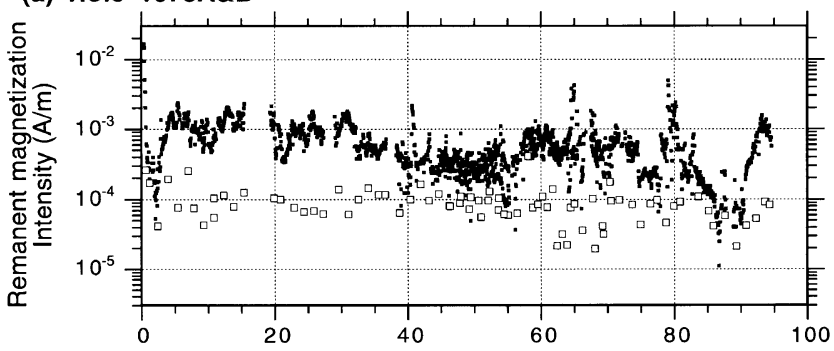

(b) Hole 1084A

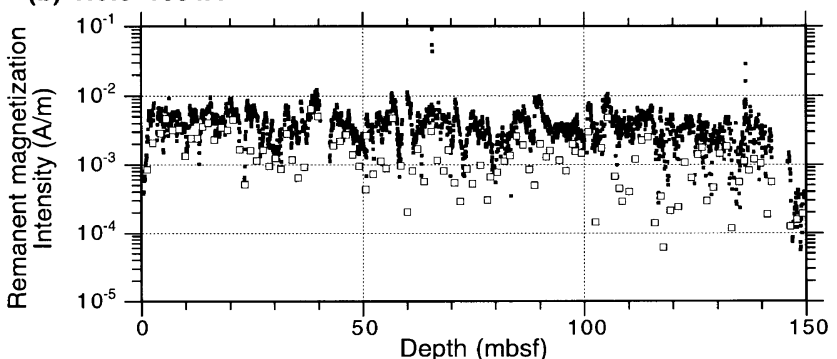

(c) Hole 1085A

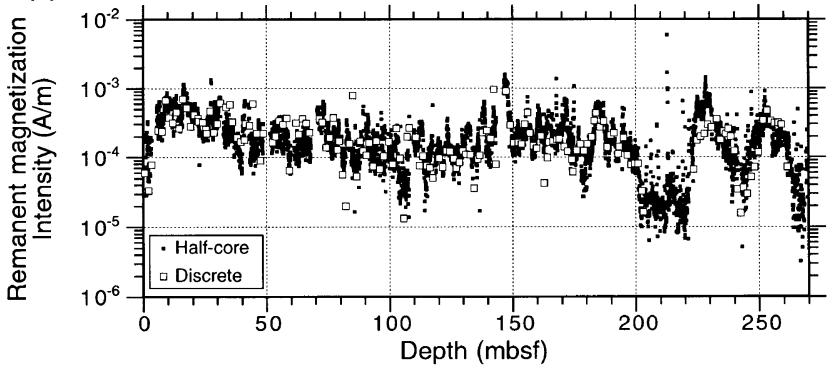

Fig. 5. Comparison of remanent intensity between half-core sections measured onboard (solid squares) and discrete samples (open squares). Discrete samples of Holes 1078A and 1078B were measured two months after core recovery, whereas measurement of discrete samples from Holes $1084 \mathrm{~A}$ and $1085 \mathrm{~A}$ were carried out onboard a few days after that of half-core sections. All data are after AF demagnetization at $20 \mathrm{mT}$. mbsf: meter below seafloor, mcd: meter composite depth.

magnetic phases occurred. We thus consider that dissolution of magnetic minerals after core recovery is responsible for the loss of magnetization. The discrete samples from Hole 1082A were stored at room temperature, whereas the samples of Hole $1082 \mathrm{C}$ were kept refrigerated. However, all four data sets formed a linear trend on the bi-logarithm plot (Fig. 3), implying that refrigeration did not prevent the decay of magnetization. Two major differences in environment before and after the core recovery are oxic-anoxic condition and temperature, and they are possible candidate for the cause of the loss of magnetization. Oxidation of sediments caused by exposure to air is thus considered to be responsible. Refrigeration does not slow down this process.

A similar decay of remanent magnetization occurred more or less at all sites visited during ODP Leg 175. For example, decay of about an order of magnitude was observed after two months at Site 1078 (Fig. 5). Very rapid alteration happened at Site 1084. Discrete samples measured only a few days after half-core sections showed significant decrease in intensity (Fig. 5). On the other hand, remanent intensities of half-core sections and discrete samples measured onboard agreed well at Site 1085 (Fig. 5), although the intensities of
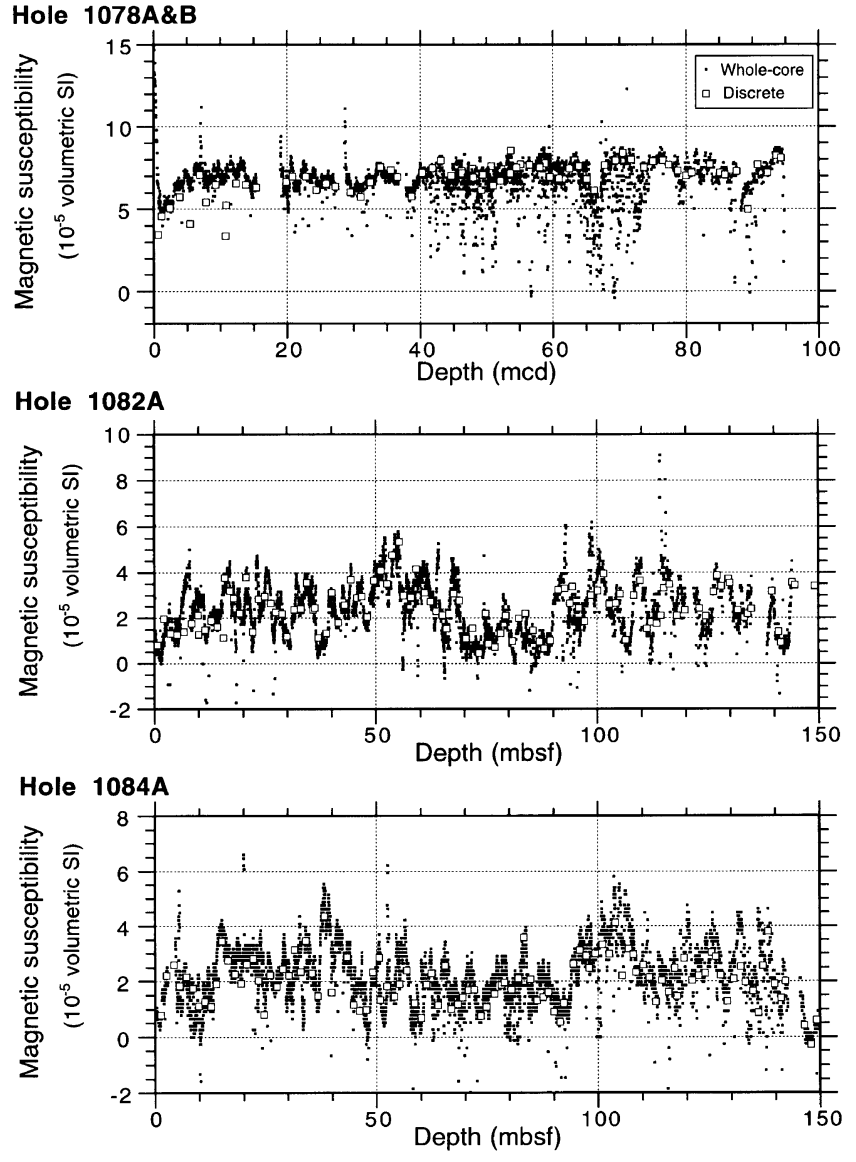

Fig. 6. Low-field magnetic susceptibility on whole-core sections measured onboard the JOIDES Resolution (solid dots) and discrete samples measured onshore (open squares).

discrete samples decreased to one-tenth after a few months. The difference in the rapidity of the alteration is probably attributable to the difference in the TOC content of the sediments. The sediments of Hole 1084A have extremely high TOC contents, as high as $20 \mathrm{wt} \%$.

Low-field magnetic susceptibility of Sites 1078, 1082, and 1084 are very low in general (Fig. 6). The susceptibility of discrete samples measured a few months or more after core recovery agrees well with that of onboard whole-core measurement in spite of the severe loss of remanent magnetization. This suggests that the contribution of ferrimagnetic minerals to the susceptibility is quite small. This result is supported by hysteresis curves, which will be shown later. Variations in susceptibility at these sites are controlled by the relative abundance of paramagnetic components such as clay minerals and of diamagnetic components such as calcium carbonates and biogenic silica.

Changes in magnetic properties with progress of the alteration were monitored using the frozen samples. Acquisition of ARM and IRM, and magnetic susceptibility were measured repeatedly for two months after the samples were unfrozen. A typical example is displayed in Fig. 7. Significant decreases of 40 to $80 \%$ in ARM and SIRM (IRM acquired at $2.5 \mathrm{~T}$ field) were observed on all samples after two months. ARM and IRM were imparted before each measurement to negate the effects of viscous decay. A small decrease in 

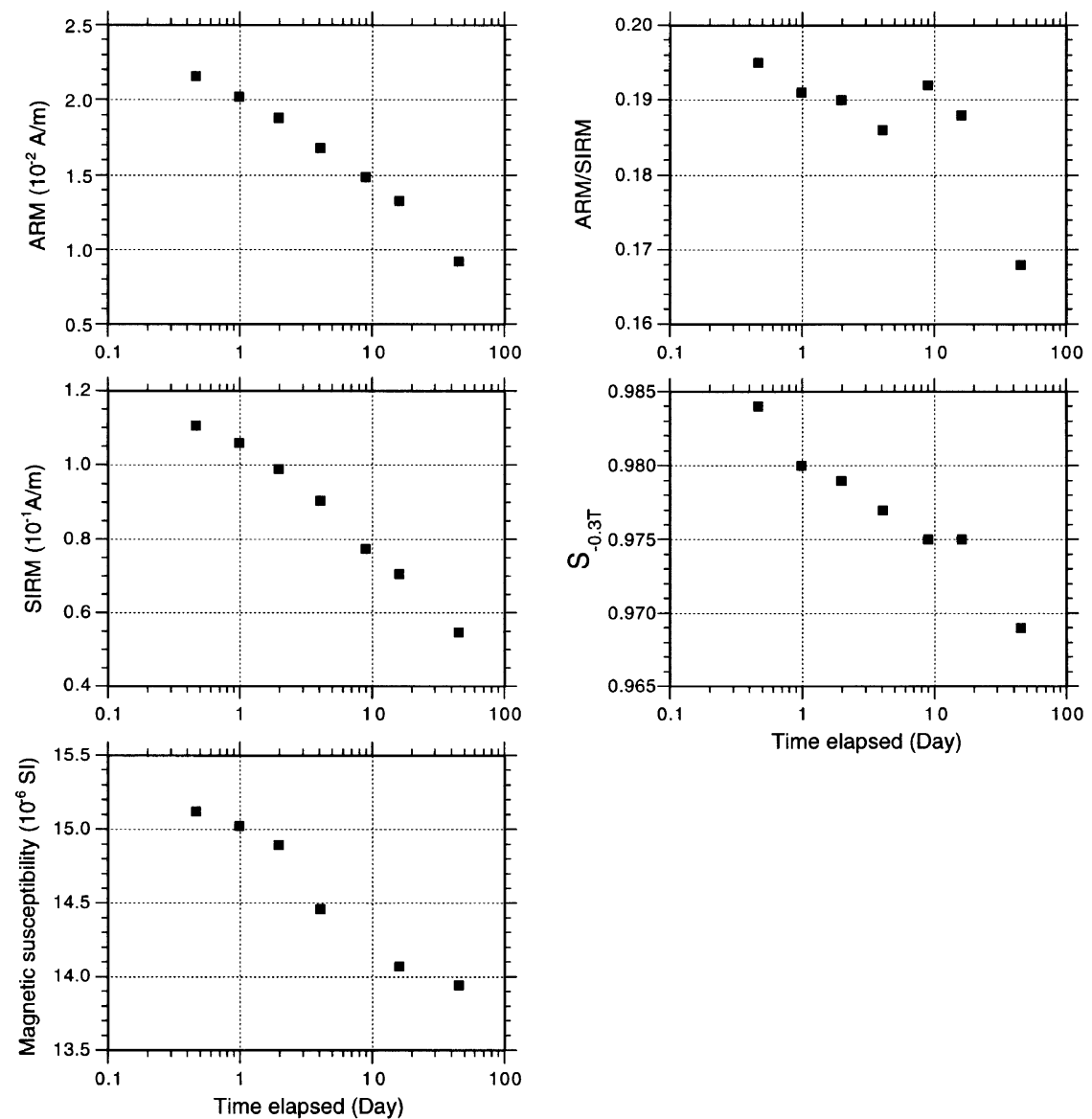

Fig. 7. Changes of magnetic properties with time for sample 1082A-3H3-130 after being thawed. Other samples showed a similar behavior. ARM and IRM were imparted prior to each measurement.

(a)

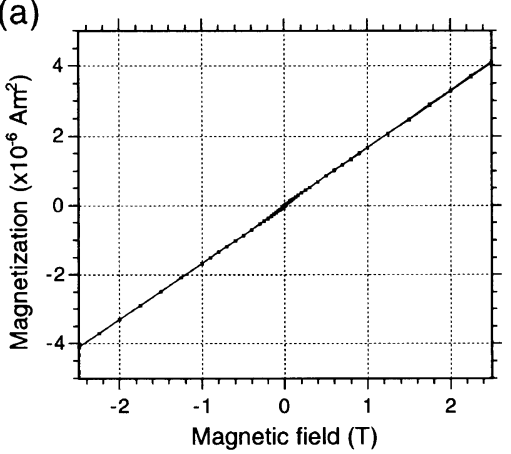

(b)

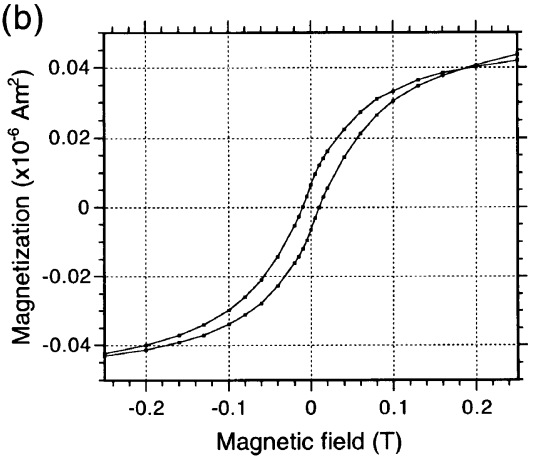

Fig. 8. Magnetic hysteresis curves measured at $250 \mathrm{~K}$ using a low-temperature susceptometer (sample 1078A-1H1-135). All samples are dominated by paramagnetic behavior (a), but a ferrimagnetic component is visible after correcting for high-field slope (b).

magnetic susceptibility, about $5 \%$ or less, was observed on samples from Site 1082, but no decrease occurred on samples from Sites 1078 and 1084. This result agrees with the fact that there was no difference in susceptibility between onboard whole-core measurements and onshore measurements of discrete samples. Many samples showed a decrease in the ratio of ARM to SIRM, which suggests an increase in magnetic grain size (Banerjee et al., 1981). The $\mathrm{S}$ ratios, $\mathrm{S}_{-0.3 \mathrm{~T}}$, are high, which indicate that remanent magnetization is carried by low-coercivity magnetic minerals such as magnetite. Most samples displayed decreases in the $\mathrm{S}$ ratios over time, which would indicate that the decay of magnetization with time is caused by loss of low-coercivity magnetic minerals rather than high-coercivity ones such as hematite.

Hysteresis curves measured at $250 \mathrm{~K}$ on the frozen samples of Sites 1078, 1082, and 1084 showed almost pure paramagnetic behavior (Fig. 8(a)). This supports the inference that the low-field magnetic susceptibility of these sites is dominated by paramagnetic minerals. After subtracting the high-field slope (paramagnetic behavior), we could determine the hysteresis parameters of the ferrimagnetic fraction of the sediments (Fig. 8(b)). Magnetic domain state was estimated from 
(a)

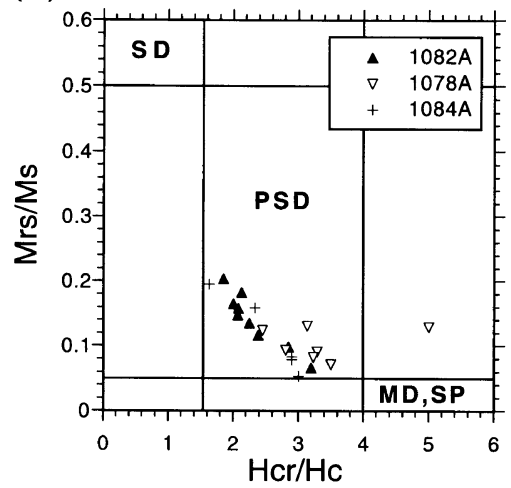

(b)

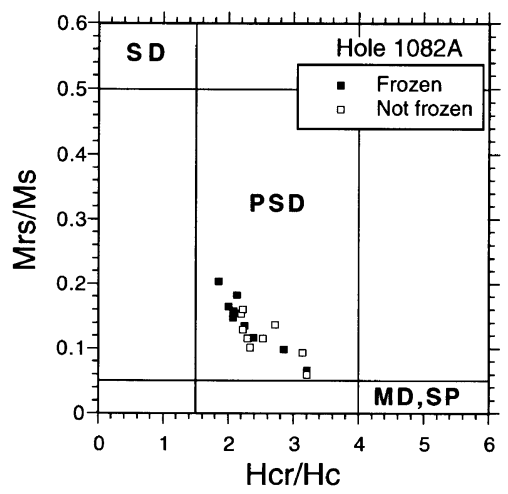

Fig. 9. Plots of hysteresis parameters: ratio of coercivity of remanence $(H c r)$ to coercivity $(H c)$ vs. ratio of saturation remanence $(\mathrm{Mrs})$ to saturation magnetization $(M s)$. (a) Frozen samples of Sites 1078A (open triangles), 1082A (solid triangles), and 1084A (crosses), and (b) comparison of Hole 1082A samples before thawing (solid squares) and two months after thawing (open squares).

(a)

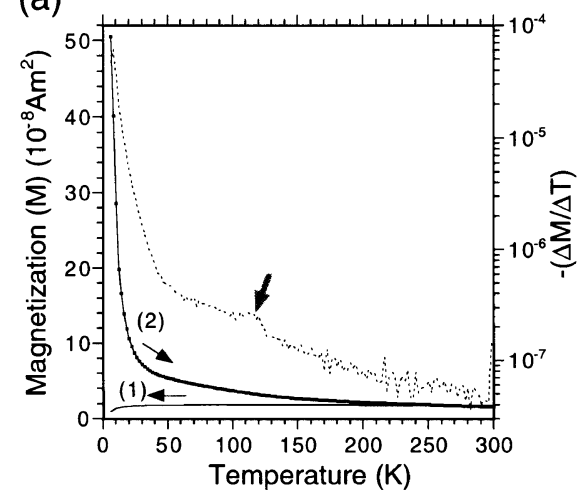

(b)

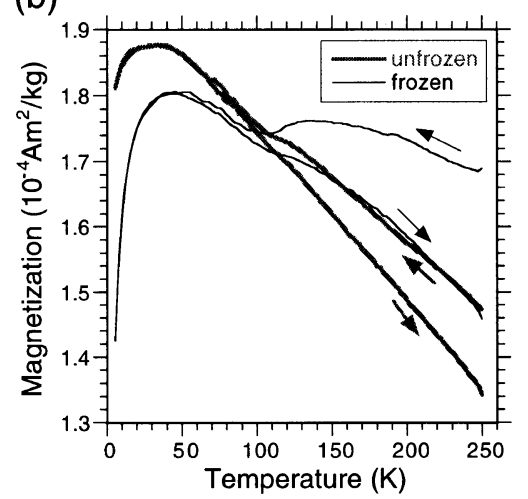

Fig. 10. (a) Example of low-temperature magnetometry (sample 1082A-7H2-110, not frozen). Changes of IRM given at $300 \mathrm{~K}$ with cycling temperature between 300 and $6 \mathrm{~K}$ [curves (1)], thermal decay of IRM imparted at $6 \mathrm{~K}$ [curve (2)], and its derivative (broken line). A hump in the derivative at about $120 \mathrm{~K}$ (thick gray arrow) suggests the Verwey transition of magnetite. (b) Change of IRM given at $250 \mathrm{~K}$ during low-temperature cycling (corresponds to curve (1) in Fig. 10(a)). Results of sample 1082A-6H3-135 are displayed. Irreversibility of cooling and warming curves above about $100 \mathrm{~K}$ is indicative of magnetite. The difference in the two curves before sediments were thawed (thin black curves) is larger than that a few months after thawing (thicker gray curves).

the hysteresis parameters: the ratio of saturation magnetization to saturation remanence $(M r s / M s)$ and the ratio of coercivity of remanence to coercivity $(\mathrm{Hcr} / \mathrm{Hc})$. On the plot of $\mathrm{Mrs} / \mathrm{Ms}$ versus $\mathrm{Hcr} / \mathrm{Hc}$ (Day et al., 1977), most samples lie within the pseudo-single-domain range (Fig. 9(a)). Hysteresis ratios on the Day plot moved lower and right after being thawed (Fig. 9(b)). This can be interpreted as an increase in the average magnetic grain size after thawing if no change in magnetic mineral composition occurred. This is consistent with the increase in magnetic grain size with time inferred from the decrease in the ratio of ARM to SIRM. Data of the samples from Site 1078A cluster toward the lower right-hand side of the other two sites (Fig. 9(a)), suggesting their larger magnetic grain size. This probably reflects a large detrital influx to the sediments in the Angola Basin by intense coastal erosion. Schmidt et al. (1999) estimated from the analysis of magnetic properties of surface sediments in the South Atlantic that magnetic minerals of detrital origin contribute more to the sediments from the Congo Basin and the Angola Basin than to the sediments off the African coast at and to the south of the Walvis Ridge, where biogenic magnetites of single domain size dominate.

Remanent magnetization in a temperature range between 6 and $250 \mathrm{~K}$ or $300 \mathrm{~K}$ was measured on frozen and unfrozen samples (Fig. 10). Changes of remanent magnetization were obscured by a strong magnetic moment at low temperature from the dominant paramagnetic component, which was induced by a small residual field in the sample space of the low- $\mathrm{T}$ susceptometer $(\sim 0.05 \mathrm{mT}$, varies with temperature and varies each time after generating a strong field) and by the remanent magnetization of blocked paramagnetic materials at low temperature. None the less, the presence of magnetites in both frozen and unfrozen samples can be concluded from the irreversibility of magnetization curves during zero-field low-temperature cycling of $250 \mathrm{~K}$ IRM (Fig. 10(b)). Magnetization during cooling down was slightly larger than during warming up above about $100 \mathrm{~K}$. The loss of remanent magnetization during the low-temperature cycle is most likely caused by passing through the magnetic isotropic point of magnetite $\left(T_{\mathrm{I}}\right)$ and the Verwey transition. The temperature of $T_{\mathrm{I}}$ is at about $130 \mathrm{~K}$ for pure magnetite, and lowered by substitution of $\mathrm{Ti}^{4+}$ (Dunlop and Özdemir, 1997). The Ver- 
wey transition is a crystallographic phase transition known to occur at 110-120 K for pure magnetite (Verwey, 1939). The magnetization loss of frozen samples during the lowtemperature cycle was significantly larger than that of the thawed samples. Another sign of the presence of magnetite is a slight increase of the slope of the thermal demagnetization curves around $100 \mathrm{~K}$, which was detected as a small increase in the derivative $(-\Delta M / \Delta T)$ (an arrow in Fig. 10(a)). This could be a manifestation of the Verwey transition. Pyrrhotite cannot be expected here because magnetic transition at 30 to $34 \mathrm{~K}$, indicative of pyrrhotite (Rochette et al., 1990), was not detected.

\section{Discussion}

Dissolution of magnetic minerals during reduction diagenesis is well known in marine sediments (e.g. Karlin and Levi, 1983; Leslie et al., 1990). In sulfate-reducing environments, magnetite is not stable and dissolves in a geologically short period of time (Canfield and Berner, 1987; Canfield et al., 1992). Kostka and Nealson (1995) showed that rapid reduction and dissolution of magnetite can also be caused by bacteria. The very low remanent intensity of the sediments in the Angola-Namibia upwelling system may partly be due to reduction diagenesis. However, the low-temperature magnetometry has indicated the presence of magnetite in the sediments of all sites, even below the depths of completion of sulfate reduction. This result suggests that some magnetite in sediments can survive sulfate reduction.

Severe and rapid loss of remanent magnetization during storage after core recovery was observed commonly in sediments of ODP Leg 175. Dehydration of the sediments cannot be the cause of the magnetization decay because the samples for onshore measurements were sealed carefully to prevent them from drying out. We have examined changes of magnetic properties with time using frozen samples, and loss of magnetization does occur in these samples as well. However, the magnetization decay observed in the experiment using the frozen samples was less than the loss of half-core sections and discrete samples. It is possible that some alteration occurred in the frozen samples before initial measurements due to accidents during transportation, which resulted in melting of the frozen samples twice for a short period of time. This could result in the frozen samples having a lower initial magnetization than fresh samples measured immediately after core recovery. An increase in the average magnetic grain size with loss of magnetization was estimated from the ratios of hysteresis parameters and the ratio of ARM to SIRM. The apparent grain-size increase can be explained by preferential dissolution of finer magnetic grains with larger ratios of volume to surface area.

Two possible processes have been proposed for the magnetization loss after core recovery; (1) oxidation of iron-sulfide phases like greigite (Hilton, 1990), and (2) transformation of fine-grained magnetite or maghemite into paramagnetic and/or antiferrimagnetic minerals like goethite (Oldfield et al., 1992). Low-temperature magnetometry suggests that the latter has occurred in the sediments of ODP Leg 175. The comparison of IRM loss during low-temperature cycle on the samples before and after thawing indicated that magnetization attributable to magnetite decreased significantly after thawing. Magnetite dissolution is consistent with the decreases of S-ratios, which implies loss of low-coercivity magnetic minerals. We, however, cannot exclude the possibility of greigite oxidation. It is difficult in general to indicate explicitly the presence or absence of greigite using rock magnetic methods. Greigite does not show any phase transition below room temperature (Torii et al., 1996). Snowball (1997a, b) and Hu et al. (1998) reported that single-domain greigite acquires a significant gyroremanent magnetization (GRM) and rotational remanent magnetization (RRM), and that AF demagnetization of greigite-bearing natural samples based on the static three-axis method showed acquisition of GRM at higher demagnetization fields. The sediments of Leg 175 did not display GRM acquisition during static AF demagnetization. We tried to identify magnetic minerals on bulk samples using Mössbauer spectroscopy, but could not succeed because of the very low concentration of magnetic minerals.

The loss of magnetization during storage may prevail widely in organic-rich sediments. Previously, paleo- and rock-magnetists may have overlooked this problem, partly because magnetometers for measuring remanent magnetization of sediment cores are not generally onboard research vessels except for the JOIDES Resolution of the ODP. Samples for environmental rock magnetism should be frozen or freeze-dried immediately after core recovery. Otherwise, the original grain-size distributions and mineral compositions may not be preserved.

Acknowledgments. We thank Volker Brüchert for providing the frozen samples, and Carl Richter and Hirokuni Oda for valuable discussions. An initial stage of the low-temperature magnetometry was done at the Institute for Rock Magnetism, University of Minnesota when T.Y. was a Visiting Fellow in October 1998. We also thank all members of the ODP Leg 175 Shipboard Scientific Party for their cooperation, and two annonymous reviewers for valuable comments to improve the paper. IRM contribution No. 00-05. The IRM is supported by grants from the National Science Foundation and the W. M. Keck Foundation.

\section{References}

Banerjee, S. K., J. King, and J. A. Marvin, Rapid method for magnetic granulometry with applications to environmental studies, Geophys. Res. Lett., 8, 333-336, 1981.

Bloemendal, J., J. W. King, F. R. Hall, and S. -J. Doh, Rock magnetism of Late Neogene and Pleistocene deep-sea sediments: relationship to sediment source, diagenetic processes, and sediment lithology, J. Geophys. Res., 97, 4361-4375, 1992.

Canfield, D. E. and R. A. Berner, Dissolution and pyritization of magnetite in anoxic sediments, Geochim. Cosmochim. Acta, 51, 645-649, 1987.

Canfield, D. E., R. Raiswell, and S. Bottrell, The reactivity of sedimentary iron minerals toward sulfide, Amer. J. Science, 292, 659-683, 1992.

Channell, J. E. T. and B. Lehman, The last two geomagnetic polarity reversals recorded in high-deposition-rate sediment drifts, Nature, 389, 712-715, 1997.

Colin, C., C. Kissel, D. Blamart, and L. Turpin, Magnetic properties of sediments in the Bay of Bengal and the Andaman Sea: impact of rapid North Atlantic Ocean climatic events on the strength of the Indian monsoon, Earth Planet. Sci. Lett., 160, 623-635, 1998.

Day, R., M. Fuller, and V. A. Schmidt, Hysteresis properties of titanomagnetites: grain-size and compositional dependence, Phys. Earth Planet. Inter., 13, 260-267, 1977.

Dunlop, D. J. and Ö. Özdemir, Rock Magnetism: Fundamentals and Frontiers, 573 pp., Cambridge University Press, Cambridge, 1997.

Giraudeau, J., B. A. Christensen, O. Hermelin, C. B. Lange, I. Motoyama, and Shipboard Scientific Party, Biostratigraphic age models and sedimentation rates along the southwest African margin, in Proc. ODP Init. 
Repts., 175, edited by G. Wefer, W. H. Berger, and C. Richter et al., pp. 543-546, Ocean Drilling Program, College Station, TX, 1998.

Guyodo, Y. and J. -P. Valet, Global changes in intensity of the Earth's magnetic field during the past $800 \mathrm{kyr}$, Nature, 399, 249-252, 1999.

Haese, R. R., H. Petermann, L. Dittert, and H. D. Schulz, The early diagenesis of iron in pelagic sediments: a multidisciplinary approach, Earth Planet. Sci. Lett., 157, 233-248, 1998.

Hartl, P. and L. Tauxe, A precursor to the Matuyama/Brunhes transitionfield instability as recorded in pelagic sediments, Earth Planet. Sci. Lett., 138, 121-135, 1996.

Hilton, J., Greigite and the magnetic properties of sediments, Limnol. Oceanogr., 35, 509-520, 1990.

Hounslow, M. K. and B. A. Maher, Source of the climate signal recorded by magnetic susceptibility variations in Indian Ocean sediments, J. Geophys. Res., 104, 5047-5061, 1999.

Hu, S., E. Appel, V. Hoffmann, W. W. Schmahl, and S. Wang, Gyromagnetic remanence acquired by greigite $\left(\mathrm{Fe}_{3} \mathrm{~S}_{4}\right)$ during static three-axis alternating field demagnetization, Geophys. J. Int., 134, 831-842, 1988.

Karlin, R. and S. Levi, Diagenesis of magnetic minerals in Recent haemipelagic sediments, Nature, 303, 327-330, 1983.

Karlin, R., M. Lyle, and G. R. Heath, Authigenic magnetite formation in suboxic marine sediments, Nature, 326, 490-493, 1987.

Kostka, J. E. and K. H. Nealson, Dissolution and reduction of magnetite by bacteria, Environ. Sci. Technol., 29, 2535-2540, 1995.

Leslie, B. W., S. P. Lund, and D. E. Hammond, Rock magnetic evidence for the dissolution and authigenic growth of magnetic minerals within anoxic marine sediments of the California continental borderland, J. Geophys. Res., 95, 4437-4452, 1990.

Murray, R. W., R. Wigley, and Shipboard Scientific Party, Interstitial water chemistry of deeply buried sediments from the southwest African margin: a preliminary synthesis of results from Leg 175, in Proc. ODP Init. Repts., 175, edited by G. Wefer, W. H. Berger, and C. Richter et al., pp. 547-553, Ocean Drilling Program, College Station, TX, 1998.

Oldfield, F., I. Darnley, G. Yates, D. E. France, and J. Hilton, Storage diagenesis versus sulfide authigenesis: possible implications in environmental magnetism, J. Paleolimnol., 7, 179-189, 1992.

Pufahl, P. K., M. A. Maslin, L. Anderson, V. Brüchert, F. Jansen, H. Lin, M. Perez, L. Vidal, and Shipboard Scientific Party, Lithostratigraphic summary for Leg 175: Angola-Benguela upwelling system, in Proc. ODP Init. Repts., 175, edited by G. Wefer, W. H. Berger, and C. Richter et al., pp. 533-542, Ocean Drilling Program, College Station, TX, 1998. Richter, C., A. Hayashida, Y. Guyodo, J. -P. Valet, and K. L. Verosub, Magnetic intensity loss and core diagenesis in long-core samples from the East Cortez Basin and the San Nicolas Basin (California Borderland), Earth Planets Space, 51, 329-336, 1999.

Roberts, A. P., J. S. Stoner, and C. Richter, Diagenetic magnetic enhancement of sapropels from the eastern Mediterranean Sea, Mar. Geol., 153, 103-116, 1999.

Rochette, P., G. Fillion, J. -L. Mattei, and M. J. Dekkers, Magnetic transition at 30-34 Kelvin in pyrrhotite: insight into a widespread occurrence of this mineral in rocks, Earth Planet. Sci. Lett., 98, 319-328, 1990.

Schmidt, A. M., T. von Dobeneck, and U. Bleil, Magnetic characterization of Holocene sedimentation in the South Atlantic, Paleoceanography, 14, 465-481, 1999.

Snowball, I. F., Gyroremanent magnetization and the magnetic properties of greigite-bearing clays in southern Sweden, Geophys. J. Int., 129, 624636, 1997a.

Snowball, I. F., The detection of single-domain greigite $\left(\mathrm{Fe}_{3} \mathrm{~S}_{4}\right)$ using rotational remanent magnetization (RRM) and the effective gyro field $\left(B_{g}\right)$ : mineral magnetic and palaeomagnetic application, Geophys. J. Int., 130, 704-716, $1997 \mathrm{~b}$.

Torii, M., Low-temperature oxidation and subsequent downcore dissolution of magnetite in deep-sea sediments, ODP Leg 161 (Western Mediterranean), J. Geomag. Geoelectr., 49, 1233-1245, 1997.

Torii, M., K. Fukuma, C. -S. Horng, and T. -Q. Lee, Magnetic discrimination of pyrrhotite- and greigite bearing sediment samples, Geophys. Res. Lett., 23, 1813-1816, 1996.

Verosub, K. L. and A. P. Roberts, Environmental magnetism: Past, present, and future, J. Geophys. Res., 100, 2175-2192, 1995.

Verwey, E. J. W., Electronic conduction of magnetite $\left(\mathrm{Fe}_{3} \mathrm{O}_{4}\right)$ and its transition point at low temperature, Nature, 144, 327-328, 1939.

Wefer, G., W. H. Berger, and C. Richter, et al., Proc. ODP Init. Repts., 175 (Part 1), 577 pp., Ocean Drilling Program, College Station, TX, 1998.

Yamazaki, T., Relative paleointensity of the geomagnetic field during Brunhes Chron recorded in North Pacific deep-sea sediment cores: orbital influence?, Earth Planet. Sci. Lett., 169, 23-35, 1999.

T. Yamazaki (e-mail: yamazaki@gsj.go.jp), P. A. Solheid, and G. M. Frost 